\title{
Intestinal mucin dynamic and leukocytic responses of chickens infected with Eimeria acervulina and fed oregano supplemented diet
}

\author{
Peter Major ${ }^{1}$, Viera Revajová ${ }^{2}$, Martin Levkut² ${ }^{2}$ Zuzana Ševčíková2 ${ }^{2}$ Viera Spišáková1, \\ Zita Faixová ${ }^{2}$, Mária Levkutová1, Ivona Kožárová3, Mária Goldová1, Mikuláš Levkut ${ }^{2}$ \\ ${ }^{1}$ Department of Epizootology and Parasitology, University of Veterinary Medicine \\ and Pharmacy, Košice, Slovak Republic \\ ${ }^{2}$ Department of Pathological Anatomy and Pathological Physiology, University \\ of Veterinary Medicine and Pharmacy, Košice, Slovak Republic \\ ${ }^{3}$ Department of Meat Hygiene and Technology, University of Veterinary Medicine \\ and Pharmacy, Košice, Slovak Republic
}

Received September 30, 2010

Accepted November 24, 2010

\begin{abstract}
We studied the effect of oregano supplemented diet on mucin dynamics in small intestine, peripheral blood leukocytes, and jejunal immunocompetent cells in ROSS 308 hybrid broilers infected with Eimeria acervulina chickens' oocyst. From the day of hatching chicks of groups 1 and 2 were fed a commercial diet without anticoccidial drug, the diet of group 3 was supplemented with oregano $\left(0.707 \mathrm{~g} \cdot \mathrm{kg}^{-1}\right)$, and that of group 4 with anticoccidial drug (Robenidin hydrochloride $\left.-33 \mathrm{mg} \cdot \mathrm{kg}^{-1}\right)$. Chickens of groups 2, 3, and 4 were inoculated with E. acervulina oocysts $\left(25.10^{3}\right)$ on day 12. The samples were collected on 3, 10, 17 days post infection (dpi). In blood on 3 dpi significant increase of leukocytes was found in group 3 compared to groups 1, 2, and 4, higher density of IgM+ cells in group 3 than group 2, and on 10 dpi phagocytic activity of group 3 was higher than group 1. Number of jejunal CD4+ and CD8+ cells in group 3 was consistent with values in group 4, despite higher density of E. acervulina meronts on $10 \mathrm{dpi}$. The quantity of jejunal mucin adherent layer of group 3 was similar to that in group 4. Counts of oocysts in faeces were lower in group 3 than group 2. Results suggest that dietary supplementation of oregano to chickens infected with $E$. acervulina has a modulating effect on some blood indicators and functions of phagocytes. The beneficial effect of oregano components on jejunal mucin quantity and its turnover is the first finding published in relation to oregano and coccidia.
\end{abstract}

Chickens, mucin, immunity, small intestine, plant oil extract, coccidia

One of the major problems facing the commercial poultry industry is coccidiosis (Naid oo et al. 2008). Prophylactic anticoccidials in-feed are used in order to limit mortalities and enhance broiler growth and production. The anticoccidials in use include the polyether (ionophor) group of chemotherapeutics, sulphonamides, pyrimidine derivates, triazinetriones and the benzenacetonitriles (Carrington et al. 2007). Unfortunately, with the widespread use of anticoccidial drugs, resistance has developed to all the drugs introduced thus far (Chapman 1998). Therefore, an increasing need for the drug-free production of foods comes from the consumers (Harper and Makatouni 2002). The use of plant extracts as a coccidiostat may reduce these difficulties and be an alternative in the control of coccidiosis. Herbal extracts are natural products and may comprise new therapeutic molecules to which resistance has not yet developed (Naid oo et al. 2008). Some herbal extracts have already been shown to possess a coccidiostatic activity (Christaki et al. 2004). The biological activity has been mainly attributed to phenolic components that exhibit antimicrobial and antioxidative activity (Burt 2004).

Essential oil obtained from Origanum vulgare comprises more than 30 ingredients, most of which are phenolic antioxidants (Vekiari et al. 1993). The dietary effect of oregano oil has already been studied in vitro (Burt 2004) and in vivo (Botsoglou et al. 2002; Garcia et al. 2007) conditions. Numerous works have been devoted to the

Address for correspondence:

Doc. MVDr. Viera Revajová PhD

Institute of Pathological Anatomy

University of Veterinary Medicine and Pharmacy,

Phone: +421915984708

Komenského 73, 04181 Košice, Slovak Republic 
antioxidant effect (Botsoglou et al. 2002), anti-inflammatory activity (Juhás et al. 2008), antibacterial properties (Burt et al. 2005), and anticoccidial activities (Giannenas et al. 2003). Mechanism for the interaction of plants including Oregano spp. with the host organism may be related to the intestinal and extraintestinal effects. Intestinal effects may be explained by the effects on the microflora (Taylor 2001), or intestinal mucosal system (Garcia et al. 2007).

Infections with Eimeria spp. induce various pathological and immunological responses that stimulate the hosts' defence mechanisms and acquired immunity. However, prior to the development of an acquired immune response, non-specific immune pathways including mucus are considered. Microflora can influence the activities of certain enzymes involved in the metabolism uptake, and incorporation of dietary nucleic acid components by enterocytes (Whitt and Savage 1988). Mucin synthesis and secretion rates are affected by the diet composition.

There is no report on the effect of oregano on the mucus adherent layer turnover in relation to the systemic and local immune response in the chickens infected with coccidia. Explanation of these aspects of intestinal coccidiosis in chickens was the main aim of the present study.

\section{Materials and Methods}

Experimental design

One hundred and twenty coccidia free (1-day-old) chicken broilers ROSS 308 were divided randomly into four groups of 30 chickens. Animals were housed in wire-floor cages with free access to feed and water and fed HYD-1 diet (TAJBA comp., Čaňa, Slovak Republic). The chicks of group 1 were fed a diet without coccidia and anticoccidial drug (negative control). The animals of group 2 (positive control), group 3, and group 4 were orally inoculated on day 12 of life with sporulated Eimeria acervulina oocysts at a dose of $25.10^{3}$ in $0.2 \mathrm{ml} \mathrm{PBS} \mathrm{(Sigma,}$ Germany). The animals of group 3 were fed a diet supplemented with oregano oil at the amount of $1.242 \mathrm{ml} \cdot \mathrm{kg}^{-1}$ feed, and chickens of group 4 were fed a diet mixed with Robenidin hydrochloride at the dose of $33 \mathrm{mg} \cdot \mathrm{kg}^{-1} \mathrm{feed}$ (Cycostat 66G, Alpharma, Belgium).

Samples of blood and intestine were taken on days 3, 10, and 17 pi (post infection) before and after necropsy from 5 randomly chosen chickens.

\section{Eimeria acervulina}

A pure culture of Eimeria acervulina was obtained from chickens (Department of Epizootology and Parasitology UVMP, Košice, Slovakia) by single oocysts isolation on agar (Tsutsumi 1972).

\section{Plant aromatic oil}

The plant aromatic oil $(100 \% \mathrm{v} / \mathrm{v})$ was isolated from the tips of oregano (Origanum vulgare L., family Lamiaceae) by steam distillation of the plant material (Calendula Ltd., Nová Lubovňa, Slovak Republic). Percentage of the main components was analysed by gas chromatography using Hewlet-Packard 5890 Series II (injection input split, capillary column HP-5, detector FIF, automatic injector HP 7673) with nitrogen as a gas carrier (Pavlišinová and Danielovič 2007). The percentage of the main component of the aromatic oil carvacrol utilized in the experiment was $60 \%$.

The aromatic oil was mixed into the diet of the experimental group of chickens at a dosage calculated according to the carvacrol content $\left(0.707 \mathrm{~g} \cdot \mathrm{kg}^{-1}\right)$ as well as according to the results of chemical and palatability tests.

White blood cell count (WBC)

Leukocytes were counted by routine laboratory method using Fried-Lukáčová solution. Differential cell counts were made on blood smears after Hemacolor (Merck, Germany) staining by counting 100 cells per a slide. Concentration of different types of WBC $\left(\mathrm{G} .1^{-1}\right)$ was determined as follows:

Total leukocyte count $/ 100$ counted cells $\times$ relative $\%$ of a different type of WBC.

Functional assays of phagocytes

Phagocytic activity (PA) of polymorphonuclears (PMN) and monocytes (MN) were examined in the whole blood, which was sampled into tubes with heparin (heparin 10-20 U $\cdot \mathrm{ml}^{-1}$ in PBS; Zentiva, Czech Republic). The MSHP (2-hydroxyethylmethacrylate synthetic hydrophilic particles; diameter $1.2 \mu \mathrm{m}$, ARTIM Prague, Czech Republic) method described by Větvička et al. (1982) was used. PA tests were performed by the evaluation of at least 200 leukocytes capable of phagocytosis. The percentage and index of phagocytic activity (\% PA, IPA) were determined by the light microscope at $\times 100$ magnification (Nikon Type 104, Japan).

Iodo-nitro-tetrazolium reductase test (INT) was used for determination of metabolic activity (MA) of PMN during phagocytosis according to the method of Mareček and Procházková (1986). The blood was sampled into EDTA (1.5\%) and leukocytes were separated by the osmotic shock method. Fifty $\mu 1$ of RPMI 1640 medium (Biotech, GmbH, Germany) were placed into eight wells of the plastic plate (96-well tissue culture plate, Sarstedt, 
USA) serving as control. Another line contained $25 \mu 1$ suspension of separated leukocytes $\left(15.10^{6}\right.$ per $\left.\mathrm{ml}\right)$ and $25 \mu 1$ 0.1\% INT (3/-4-iodophenyl-2-/4-nitrophenyl/-5-phenyl/-tetrazolium chloride, Sigma-Aldrich, USA). Ten $\mu 1$ of Zymozan solution (Sigma-Aldrich, USA) as stimulating cells were supplemented into the first four wells and PBS, as no stimulating cells were added in the same content into another four wells. Immediately after 45 min incubation at $37^{\circ} \mathrm{C}$, reaction was stopped by $100 \mu 1$ hydrochloric acid per each well and centrifuged at 200$300 \mathrm{~g}$ during $10 \mathrm{~min}$. Supernatant was removed and the plastic plate was dried out at $37-40^{\circ} \mathrm{C}$ during $30-45 \mathrm{~min}$. Then, $100 \mu \mathrm{l}$ DMSO (dimetylsulfoxid, 99.8\%, Sigma-Aldrich Chemie) were added into each well and left for $10 \mathrm{~min}$ at $20^{\circ} \mathrm{C}$. Optical density (OD) was measured spectrophotometrically at $450 \mathrm{~nm}$. The results were described as the index of the metabolic activity (IMA) based on the ratio between the spontaneous activity and zymozan stimulation activity.

\section{Flow cytometry of blood}

Mononuclear cells from heparinized blood were separated using the Histopaque-1077 (Sigma) sedimentation gradient with centrifugation at $400 \mathrm{~g}$ for $40 \mathrm{~min}$. Cells at the interface were collected and washed twice with PBS by centrifugation at $110 \mathrm{~g}$ for $5 \mathrm{~min}$. Cell viability was determined by trypan blue exclusion and it exceeded $95 \%$.

The direct immunofluorescence method and labelled primary mouse anti-chicken monoclonal antibodies CD3, CD4, CD8, IgM (Southern Biotechnology Associates, Inc., Birmingham, USA) in working dilution were used for flow cytometry.

As control, a polyclonal goat anti-mouse FITC-conjugated immunoglobulin F(ab') fragment (Dako, Denmark) was used at the working dilution 1:50 with phosphate-buffered saline and 0.1\% sodium azide $\left(\mathrm{PBS}+\mathrm{NaN}_{3}\right)$.

After separation the lymphocytes were washed twice with phosphate-buffer saline (PBS). Fifty $\mu$ l of cellular suspension $\left(10^{6}\right.$ lymphocytes in PBS) and $2 \mu \mathrm{l}$ of specific, or $50 \mu \mathrm{l}$ of control MoAbs were mixed and incubated at room temperature for $15 \mathrm{~min}$. After being stained the cells were washed once in PBS, and resuspended in $0.2 \mathrm{ml}$ of PBS with $0.1 \%$ paraformaldehyde.

The FACScan cytometer and Cell Quest programme (Becton Dickinson, Germany) were used for measurement and analysis of stained blood lymphocytes. The fluorescence data were collected on at least 10,000 lymphocytes and the results were expressed as the relative percentage of lymphocyte subpopulation, which was positive for a specific $\mathrm{MoAb}$. The absolute peripheral blood lymphocyte counts of positive subpopulation were computed as follows:

Concentrations of lymphocyte $\times$ relative size of subpopulation $(\%) / 100$.

Evaluation of intestinal mucus

Samples of the intestine were taken from the central segment of the duodenum between the entry of biliary ducts and Meckel's diverticulum (jejunum), up to the ileocaecal junction (ileum) and caudal part of the caecum. The samples were processed in modification of Thompson and Applegate (2006). Briefly, the samples of $1 \mathrm{~cm}$ length were gently washed by $\mathrm{NaCl}\left(150 \mathrm{mmol} \cdot \mathrm{l}^{-1}\right)$. Then extraction was done for $2 \mathrm{~h}$ with $0.1 \%$ solution of alcian blue 8GX (AppliChem, Germany) dissolved in buffer with included $0.16 \mathrm{~mol} \cdot \mathrm{l}^{-1}$ saccharose and $0.05 \mathrm{~mol} \cdot \mathrm{l}^{-1}$ sodium acetate (both from Centralchem, Slovakia) adjusted with $36-38 \% \mathrm{HCl}$ to $\mathrm{pH} 5.8$. After this the samples were washed with $0.25 \mathrm{~mol} \cdot \mathrm{l}^{-1}$ saccharose for $15 \mathrm{~min}$ and again for next $45 \mathrm{~min}$. Finally, the tissues were immersed in $10 \mathrm{~g} \cdot 1^{-1}$ solution of docusate sodium (Aldrich, Germany) overnight at room temperature, centrifuged at $700 \mathrm{~g}$ and evaluated spectrophotometrically at the wavelength of $630 \mathrm{~nm}\left(\right.$ Opsys MR ${ }^{\mathrm{TM}}$, Dynex Technologies Inc., USA). Alcian blue solution was used as a standard. The amount of absorbed dye was evaluated at $\mu \mathrm{g}$ of Alcian blue on $1 \mathrm{~cm}^{2}$ of the intestinal tissue.

Immunohistochemistry

Frozen sections $(7 \mu \mathrm{m})$ were mounted on glass slides, dried at the room temperature, fixed in cold acetone for $2 \mathrm{~min}$ and freeze-stored. Sections were then incubated for $1 \mathrm{~h}$ with unlabelled mouse anti-chicken primary monoclonal antibodies CD4, CD8 $\alpha$, and Monocytes/Macrophages (SouthernBiotech comp., USA) diluted 1:10 with PBS. Vectastain Elite ABC kit (Vector Laboratories, UK) was used for detection of primary antibodies. The specific colour reaction was induced by 3,3 diaminobenzidine in Tris-buffered hydrochloric acid.

The cells in the jejunum were counted in the villus epitelium and lamina propria from the base of villi toward the point. Twenty appropriate areas were chosen randomly from each of these sites in the gut. Measurements were taken by the light microscope at $\times 400$ magnification. The positive stained cells within each randomly selected area were counted using the calibrated ocular graticule LTD $0.25 \mathrm{~mm}$ Id $\times$ Grd (Electronmicroscopy, UK). The appearance of positive lymphocytes was expressed in numbers per a square millimeter.

Histological processing

The tissue samples were obtained from duodenum and jejunum, fixed in $10 \%$ neutral buffered formaline and subjected to routine laboratory method.

Counting of oocysts by McMaster method

Quantitative technique was used for counting of oocysts in one gram of faeces (OPG). Three grams of faeces were diluted in $42 \mathrm{ml}$ of tap water, sieved to test tube and centrifuged at $700 \mathrm{~g}$ for $2 \mathrm{~min}$. After removing supernatant, flotation solution was added, mixed and oocysts were counted in the McMaster chamber (Manual 1989). 
Counting the developmental stages of coccidia

The developmental stages of E. acervulina were counted under $\times 400$ magnification in 5 randomly selected intestinal villi using light microscope (Nikon LABOPHOT 2 with camera adapter DS Camera Control Unit DSU2). The area of each villus was measured on digital images using Nis-Elements 3.0 software. Developmental stages (schizonts, gamonts) were counted and expressed in numbers per square millimetre of epithelium and statistically analysed.

Statistical analysis

Statistical analysis was done using GraphPad software and one-way analysis of variance (ANOVA) with post hoc Tukey multiple comparison test. Differences between the mean values for the groups of chicken were considered significant when $p<0.05$.

\section{Results}

Count of white blood cells is summarized in Table 1. The total number of leukocytes in the peripheral blood was significantly higher in chickens fed the oregano supplemented diet compared to other experimental groups on $3 \mathrm{dpi}$. There was a significant decrease in

Table 1. White blood cells count $\left(\mathrm{G} \cdot \mathrm{l}^{-1}=10^{9} \cdot \mathrm{l}^{-1}\right)$ in peripheral blood $(\mathrm{n}=5$, average $\pm \mathrm{SD})$ of chickens

\begin{tabular}{lccccc}
\hline & $\begin{array}{c}\text { Days post } \\
\text { infection }\end{array}$ & $\begin{array}{c}\text { Group 1 } \\
\text { (negative control) }\end{array}$ & $\begin{array}{c}\text { Group 2 } \\
\text { (positive control) }\end{array}$ & $\begin{array}{c}\text { Group 3 } \\
\text { (oregano) }\end{array}$ & $\begin{array}{c}\text { Group 4 } \\
\text { (anticoccidial drug) }\end{array}$ \\
\hline Leukocytes & 3 & $12.52 \pm 0.88^{\mathrm{c}}$ & $11.06 \pm 0,30^{\mathrm{de}}$ & $14.04 \pm 0.54^{\text {def }}$ & $11.90 \pm 0.19^{\mathrm{f}}$ \\
& 10 & $15.06 \pm 1.15$ & $14.84 \pm 1.63$ & $15.74 \pm 0.69$ & $14.44 \pm 0.89$ \\
Lymphocytes & 17 & $18.02 \pm 1.87$ & $17.64 \pm 2.38$ & $17.10 \pm 1.91$ & $15.58 \pm 1.17$ \\
& 3 & $9.89 \pm 0.77$ & $9.64 \pm 0.55$ & $10.34 \pm 0.71$ & $9.34 \pm 0.47$ \\
Heterophils & 10 & $10.81 \pm 0.76$ & $9.50 \pm 1.86$ & $10.43 \pm 1.27$ & $10.40 \pm 0.84$ \\
& 17 & $13.15 \pm 0.86$ & $11.17 \pm 1.53$ & $12.58 \pm 1.17$ & $11.99 \pm 1,67$ \\
& 3 & $2.55 \pm 0.18^{\mathrm{a}}$ & $1.24 \pm 0.09^{\mathrm{abc}}$ & $3.02 \pm 1.11^{\mathrm{d}}$ & $2.46 \pm 0.39^{\mathrm{b}}$ \\
& 10 & $4.08 \pm 0.63$ & $5.12 \pm 1.00$ & $5.11 \pm 0.80$ & $3.93 \pm 0.42$ \\
Eosinophils & 17 & $4.83 \pm 1.06$ & $6.36 \pm 0.99^{\mathrm{c}}$ & $4.49 \pm 1.19$ & $3.73 \pm 1.02^{\mathrm{d}}$ \\
& 3 & $0.08 \pm 0.07$ & $0.04 \pm 0.06$ & $0.14 \pm 0.10$ & $0.06 \pm 0.07$ \\
& 10 & $0.12 \pm 0.13$ & $0.34 \pm 0.33$ & $0.09 \pm 0.09$ & $0.12 \pm 0.12$ \\
\hline
\end{tabular}

Means with different superscript letters in the same line differ significantly at:

${ }^{a b} p>0.05 ;{ }^{c d} p>0.01 ;{ }^{e f} p>0.001$

Table 2. The values of functional indicators of peripheral blood phagocytes in chickens $(n=5$, average \pm SD)

\begin{tabular}{lccccc}
\hline & $\begin{array}{c}\text { Days post } \\
\text { infection }\end{array}$ & $\begin{array}{c}\text { Group 1 } \\
\text { (negative control) }\end{array}$ & $\begin{array}{c}\text { Group 2 } \\
\text { (positive control) }\end{array}$ & $\begin{array}{c}\text { Group 3 } \\
\text { (oregano) }\end{array}$ & $\begin{array}{c}\text { Group 4 } \\
\text { (anticoccidial drug) }\end{array}$ \\
\hline PA (\%) & 3 & $45.00 \pm 1.71$ & $47.20 \pm 0.07$ & $49.80 \pm 1.08$ & $49.20 \pm 1.17$ \\
& 10 & $31.60 \pm 1.22^{\mathrm{ae}}$ & $56.00 \pm 1.79^{\mathrm{f}}$ & $61.80 \pm 1.78^{\mathrm{f}}$ & $47.80 \pm 1.79^{\mathrm{b}}$ \\
& 17 & $49.60 \pm 1.65^{\mathrm{ac}}$ & $57.00 \pm 0.83^{\mathrm{b}}$ & $51.20 \pm 0.40^{\mathrm{d}}$ & $49.20 \pm 1.71^{\mathrm{a}}$ \\
IPA & 3 & $5.10 \pm 0.32^{\mathrm{a}}$ & $6.70 \pm 1.07^{\mathrm{b}}$ & $5.00 \pm 0.20^{\mathrm{a}}$ & $5.90 \pm 0.74$ \\
& 10 & $4.50 \pm 0.33^{\mathrm{ce}}$ & $5.90 \pm 0.18^{\mathrm{f}}$ & $5.70 \pm 0.37^{\mathrm{f}}$ & $5.50 \pm 0.12^{\mathrm{d}}$ \\
MAP & 17 & $5.60 \pm 0.25$ & $5.90 \pm 0.43$ & $6.10 \pm 0.40$ & $5.70 \pm 0.63$ \\
& 3 & $1.31 \pm 0.06$ & $1.45 \pm 0.14$ & $1.36 \pm 0.40$ & $1.38 \pm 0.06$ \\
& 10 & $1.18 \pm 0.12^{\mathrm{ac}}$ & $1.43^{\mathrm{b}} \pm 0.12^{\mathrm{b}}$ & $1.52 \pm 0.11^{\mathrm{d}}$ & $1.47 \pm 0.09^{\mathrm{d}}$ \\
\hline
\end{tabular}

Means with different superscript letters in the same line differ significantly at:

${ }^{a b} p>0.05 ;{ }^{c d} p>0.01 ;{ }^{e f} p>0.001, \mathrm{PA}$ - phagocytic activity, IPA - index of phagocytic activity, MAP - metabolic activity of phagocytes 
Table 3. Lymphocyte subpopulations count $\left(\mathrm{G} \cdot 1^{-1}=10^{9} \cdot 1^{-1}\right)$ and $\mathrm{CD} 4 / \mathrm{CD} 8$ ratio in peripheral blood $(\mathrm{n}=5$, average $\pm \mathrm{SD})$ of chickens

\begin{tabular}{lccccc}
\hline & $\begin{array}{c}\text { Days post } \\
\text { infection }\end{array}$ & $\begin{array}{c}\text { Group 1 } \\
\text { (negative control) }\end{array}$ & $\begin{array}{c}\text { Group 2 } \\
\text { (positive control) }\end{array}$ & $\begin{array}{c}\text { Group 3 } \\
\text { (oregano) }\end{array}$ & $\begin{array}{c}\text { Group 4 } \\
\text { (anticoccidial drug) }\end{array}$ \\
\hline CD3 & 3 & $4.83 \pm 1.55$ & $5.10 \pm 2.29$ & $5.99 \pm 0.98$ & $6.19 \pm 1.70$ \\
& 10 & $9.47 \pm 0.64$ & $8.05 \pm 1.71$ & $9.07 \pm 1.35$ & $9.24 \pm 1.09$ \\
CD4 & 17 & $10.88 \pm 1.17$ & $9.48 \pm 1.45$ & $10.97 \pm 1.37$ & $10.04 \pm 1.31$ \\
& 3 & $3.12 \pm 0.91$ & $3.35 \pm 1.18$ & $3.89 \pm 1.03$ & $3.96 \pm 0.43$ \\
& 10 & $6.65 \pm 0.66$ & $6.64 \pm 1.85$ & $6.99 \pm 1.57$ & $7.37 \pm 0.54$ \\
CD8 & 17 & $7.40 \pm 1.05$ & $6.63 \pm 1.31$ & $7.83 \pm 0.65$ & $6.74 \pm 1.00$ \\
& 3 & $2.45 \pm 0.88$ & $1.79 \pm 0.89$ & $2.42 \pm 0.69$ & $2.50 \pm 0.75$ \\
CD4/CD8 & 10 & $2.47 \pm 0.37^{\mathrm{c}}$ & $1.41 \pm 0.35^{\mathrm{d}}$ & $1.92 \pm 0.37$ & $1.98 \pm 0.35$ \\
& 17 & $2.46 \pm 0.66$ & $2.28 \pm 1.29$ & $2.85 \pm 0.88$ & $2.86 \pm 0.37$ \\
& 3 & $1.31 \pm 0.23$ & $2.06 \pm 0.58$ & $1.74 \pm 0.73$ & $1.66 \pm 0.4$ \\
IgM & 10 & $2.74 \pm 0.52$ & $4.93 \pm 1.81$ & $3.87 \pm 1.56$ & $3.80 \pm 0.59$ \\
& 17 & $3.20 \pm 0.96$ & $3.87 \pm 1.75$ & $2.99 \pm 0.99$ & $2.41 \pm 0.56$ \\
& 3 & $0.30 \pm 0.07$ & $0.14 \pm 0.10^{\mathrm{a}}$ & $0.44 \pm 0.19^{\mathrm{b}}$ & $0.19 \pm 0.13$ \\
& 10 & $0.45 \pm 0.19$ & $0.50 \pm 0.17$ & $0.76 \pm 0.18$ & $0.59 \pm 0.16$ \\
& 17 & $0.63 \pm 0.26$ & $0.90 \pm 0.23$ & $0.91 \pm 0.17$ & $0.87 \pm 0.20$ \\
\hline
\end{tabular}

Means with different superscript letters in the same line differ significantly at:

${ }^{\mathrm{ab}} p>0.05 ;{ }^{\mathrm{cd}} p>0.01$

Table 4. Lymphocyte subpopulations (CD4, CD8) and macrophages count in jejunum $(\mathrm{n}=20$, mean \pm SD) of chickens. The positive lymphocytes are expressed in numbers per a square millimetre

\begin{tabular}{cccccc}
\hline & $\begin{array}{c}\text { Days post } \\
\text { infection }\end{array}$ & $\begin{array}{c}\text { Group 1 } \\
\text { (negative control) }\end{array}$ & $\begin{array}{c}\text { Group 2 } \\
\text { (positive control) }\end{array}$ & $\begin{array}{c}\text { Group 3 } \\
\text { (oregano) }\end{array}$ & $\begin{array}{c}\text { Group 4 } \\
\text { (anticoccidial drug) }\end{array}$ \\
\hline CD4 & 3 & $1434.21 \pm 277.46^{\mathrm{e}}$ & $1859.99 \pm 195.52^{\mathrm{f}}$ & $1456.62 \pm 242.47$ & $1624.69 \pm 314.85$ \\
& 10 & $1512.64 \pm 263.82^{\mathrm{e}}$ & $1949.63 \pm 198.86^{\mathrm{f}}$ & $1680.71 \pm 214.18$ & $1703.12 \pm 245.71$ \\
& 17 & $1568.67 \pm 187.26^{\text {acef }}$ & $1893.60 \pm 189.36^{\mathrm{f}}$ & $1848.79 \pm 214.18^{\mathrm{d}}$ & $1815.17 \pm 224.99^{\mathrm{b}}$ \\
$\mathrm{CD} 8$ & 3 & $997.22 \pm 209.22^{\text {ac }}$ & $1310.96 \pm 217.85^{\mathrm{d}}$ & $1277.34 \pm 241.93^{\mathrm{b}}$ & $1266.14 \pm 240.84^{\mathrm{b}}$ \\
& 10 & $1120.47 \pm 222.04^{\mathrm{e}}$ & $1658.31 \pm 174.13^{\mathrm{f}}$ & $1579.87 \pm 269.75^{\mathrm{f}}$ & $1512.64 \pm 230.20^{\mathrm{f}}$ \\
& 17 & $1310.96 \pm 204.04^{\mathrm{e}}$ & $1803.97 \pm 239.19^{\mathrm{f}}$ & $1893.60 \pm 203.45^{\mathrm{f}}$ & $1747.94 \pm 230.20^{\mathrm{f}}$ \\
$\mathrm{Mp}$ & 3 & $1243.73 \pm 279.83^{\mathrm{ce}}$ & $1893.60 \pm 216.63^{\mathrm{f}}$ & $1736.74 \pm 216.63^{\mathrm{d}}$ & $1647.10 \pm 182.26^{\mathrm{f}}$ \\
& 10 & $1333.37 \pm 201.50^{\mathrm{ac}}$ & $1624.69 \pm 256.73^{\mathrm{b}}$ & $1613.49 \pm 249.97^{\mathrm{b}}$ & $1568.67 \pm 227.32^{\mathrm{d}}$ \\
& 17 & $1423.00 \pm 174.13^{\mathrm{a}}$ & $1647.10 \pm 246.78^{\mathrm{b}}$ & $1579.87 \pm 184.42$ & $1613.49 \pm 186.55$ \\
\hline
\end{tabular}

Means with different superscript letters in the same line differ significantly at:

${ }^{\mathrm{ab}} p>0.05 ;{ }^{\mathrm{cd}} p>0.01 ;{ }^{\text {ef }} p>0.001$. Mp - macrophages

the number of heterophils of E. acervulina infected chickens compared to other groups on 3 dpi. However, on dpi 17 higher frequency of heterophils was found in E. acervulina infected chickens compared to birds treated with the anticoccidial drug.

The percentage of phagocytic activity was significantly increased in all experimental groups compared to control chickens on dpi 10 (Table 2). Significant increase was also found on dpi 17 in E. acervulina infected and oregano treated chickens compared to control birds. Index of phagocytic activity was the highest in E. acervulina infected chickens on dpi 3 and 10. Metabolic activity showed significant increase in all experimental groups compared to controls on dpi 10, with the highest values in the oregano treated group, however, on dpi 17 values in E. acervulina infected group were higher compared to oregano treated birds. 
Table 5. Influence of Eimeria acervulina infection, anticoccidial drug and essential oil from Origanum vulgare L. on mucus production in the gastrointestinal tract of broiler chickens ROSS $308(\mathrm{n}=5$, average \pm SEM)

\begin{tabular}{lccccc}
\hline $\begin{array}{l}\text { Intestine } \\
\text { tract }\end{array}$ & $\begin{array}{c}\text { Days post } \\
\text { infection }\end{array}$ & $\begin{array}{c}\text { Group 1 } \\
\text { (negative control) }\end{array}$ & $\begin{array}{c}\text { Group 2 } \\
\text { (positive control) }\end{array}$ & $\begin{array}{c}\text { Group 3 } \\
\text { (oregano) }\end{array}$ & $\begin{array}{c}\text { Group 4 } \\
\text { (anticoccidial drug) }\end{array}$ \\
\hline Duodenum & 3 & $40.66 \pm 2.02$ & $32.06 \pm 1.24$ & $35.51 \pm 2.45$ & $33.94 \pm 1.95$ \\
& 10 & $41.80 \pm 1.79$ & $55.40 \pm 2.10$ & $49.80 \pm 1.65$ & $44.55 \pm 1.94$ \\
Jejunum & 17 & $32.10 \pm 1.65$ & $28.30 \pm 1.64$ & $29.10 \pm 1.54$ & $26.10 \pm 0.98$ \\
& 3 & $48.92 \pm 1.35^{\mathrm{ac}}$ & $31.95 \pm 1.04^{\mathrm{ad}}$ & $42.29 \pm 2.39^{\mathrm{db}}$ & $31.07 \pm 2.10^{\mathrm{cb}}$ \\
& 10 & $35.24 \pm 2.36^{\mathrm{a}}$ & $53.73 \pm 5.25^{\mathrm{abc}}$ & $41.00 \pm 1.06^{\mathrm{b}}$ & $42.47 \pm 2.35^{\mathrm{c}}$ \\
& 17 & $33.30 \pm 1.75$ & $28.30 \pm 1.64$ & $29.10 \pm 1.54$ & $24.90 \pm 0.76$ \\
\hline
\end{tabular}

Means with identical superscript letters in the same line differ significantly at $p<0.05$

Table 6. Count of Eimeria acervulina meronts $/ 1 \mathrm{~mm}^{2}$ in duodenum and jejunum of chickens broilers

\begin{tabular}{lcccc}
\hline $\begin{array}{l}\text { Intestine } \\
\text { tract }\end{array}$ & $\begin{array}{c}\text { Days post } \\
\text { infection }\end{array}$ & $\begin{array}{c}\text { Group 2 } \\
\text { (positive control) }\end{array}$ & $\begin{array}{c}\text { Group 3 } \\
\text { (oregano) }\end{array}$ & $\begin{array}{c}\text { Group 4 } \\
\text { (anticoccidial drug) }\end{array}$ \\
\hline Duodenum & 3 & $63.5 \pm 40.8$ & $54.6 \pm 23.5$ & $73.2 \pm 43.8$ \\
& 10 & $804.6 \pm 448.4^{\mathrm{a}}$ & $1423.0 \pm 551.0^{\mathrm{e}}$ & $8.3 \pm 11.4^{\mathrm{bf}}$ \\
Jejunum & 17 & $43.8 \pm 22.4^{\mathrm{a}}$ & $37.0 \pm 25.3^{\mathrm{a}}$ & $0.0 \pm 0.0^{\mathrm{b}}$ \\
& 3 & $65.0 \pm 46.1$ & $56.5 \pm 30.7$ & $45.8 \pm 26.0$ \\
& 10 & $1253.0 \pm 666.9^{\mathrm{c}}$ & $1346.0 \pm 294.0^{\mathrm{e}}$ & $8.1 \pm 7.8$ \\
\hline
\end{tabular}

Means with different superscript letters in the same line differ significantly at:

${ }^{\mathrm{ab}} p>0.05 ;{ }^{\mathrm{cd}} p>0.01 ;{ }^{\mathrm{ef}} p>0.001$

Table 7. Count of Eimeria acervulina oocysts per gram faeces $\left(1.10^{3}\right)$ in chickens

\begin{tabular}{|c|c|c|c|c|c|c|c|c|}
\hline $\begin{array}{l}\text { Days pi/ } \\
\text { groups }\end{array}$ & $1-4$ & 5 & 6 & 7 & 8 & 9 & 10 & $11-17$ \\
\hline Group 2 (PK) & 0 & 380.000 & 124.700 & 66.100 & 44.500 & 11.600 & 42.300 & 0 \\
\hline Group $3(\mathrm{O})$ & 0 & 105.500 & 91.000 & 16.200 & 40.100 & 4.700 & 4.700 & 0 \\
\hline
\end{tabular}

$\mathrm{PK}$ - positive control, $\mathrm{O}$ - oregano

Immunophenotyping of blood cells (Table 3) showed lower number of CD8+ cells in E. acervulina infected chickens compared to control birds on dpi 10 . The values of IgM+ cells was higher in oregano treated chickens compared to E. acervulina infected animals on dpi 3.

Number of jejunal CD4+ cells was higher on dpi 3 and 10 in E. acervulina infected chickens, and on $17 \mathrm{dpi}$ in all experimental groups compared to the control group (Table 4 ). The values of CD8+ cells and macrophages in jejunum were significantly higher in experimental groups compared to controls on dpi 3, 10 and 17.

The density of the mucin adherent layer in the duodenum (Table 5) was not changed in studied groups of chickens on dpi 3,10, and 17. The mucus content in the jejunum was thinner in E. acervulina infected and anticoccidial drug treated chickens than the control group on 3 dpi. However, on dpi 10 the mucus layer was thicker in E. acervulina infected chickens compared to other experimental groups.

The number of meronts in the duodenum and jejunum of anticoccidial drug treated chickens was significantly decreased on dpi 10, and disappeared on dpi 17 (Table 6). However, 
in oregano treated and control chickens some meronts were found in the intestine on 17 dpi.

The number of oocysts in faeces (Table 7) was increased several times in E. acervulina infected group compared to oregano treated chickens on days 5, 7, 9, and 10 .

\section{Discussion}

The current experiment demonstrated that supplementation of oregano to the diet of chickens infected with E. acervulina increased the quantity of peripheral blood leukocytes and heterophils three days after infection. Changes in the peripheral blood leukocytes were not found in intact chickens fed the diet supplemented with $0.707 \mathrm{~g} \cdot \mathrm{kg}^{-1}$ oregano (Revajova et al. 2010). However, infection with coccidia induced the inflammatory process with a damage of the mucus and leakage of plasma proteins (Williams 2005). It is suggested that chickens infected with E. acervulina and receiving oregano components in feed were able to mobilize the higher number of leukocytes and heterophils in blood. The results also showed increased phagocytic activity and metabolic activity of phagocytes in chickens fed the diet supplemented with oregano in the culminated period of multiplication E. acervulina meronts in the duodenum and jejunum. Recently, we have demonstrated (Revajova et al. 2010) increased lymphocytic activity to mitogen in chickens free of pathogens fed the oregano supplemented diet, which is consistent with the influence of that etheric oil on some functional immunological indicators in the current experiment. Finally, several experiments demonstrated antinflammatory properties of oregano (Burt 2004; Revajova et al. 2010).

To obtain more information about the quantity of cells included into the natural and acquired immunity after supplementation of oregano or anticoccidial drug in feed we chose to follow lymphocyte subpopulations and macrophages.

Evaluation of lymphocyte subpopulations in peripheral blood demonstrates the decreased number of CD8+ cells in E. acervulina infected group which could be caused by the moving of these cells into the coccidia infected intestine. Interestingly, the number of CD8+ cells did not change in the coccidia infected group fed the oregano supplemented diet, or treated with anticoccidial drug. Higher density of IgM+ cells in the peripheral blood of chickens fed the diet supplemented with oregano compared to chickens infected only with coccidia on day 3 after infection suggests earlier activation of the cells responsible for antibody production.

The increased number of CD4+ and CD8+ lymphocytes in the intestine of animals infected only with $E$. acervulina is consistent with the immune response to coccidia and is well documented in previous studies (Lillehoj and Bacon 1991). The density of CD4+ cells in the intestine of chickens fed the diet supplemented with oregano was similar to that in groups of chickens with anticoccidial drug and non-infected animals despite the severe density of meronts in the duodenum and jejunum in the oregano group.

Changes in the quantity of mucin among the groups were found only in the jejunum whereas mucin density was not affected in the duodenum in spite of similar invasion of the duodenal epithelium with coccidia as in the jejunum. Peek et al. (2009) suggest that higher mucosal turnover in the jejunum might represent a lower mucosal protection against an Eimeria infection. The phenomenon of changes of mucin quantity in the jejunum compared to the mucin layer in the duodenum was documented in our experiment. This finding shows that jejunal mucus is more sensitive to infection by coccidia than the duodenal mucus. A decrease in the mucin quantity in the E. acervulina infected group and the group treated with anticoccidial drug on day 3 after infection could be connected with the increased mucosal permeability and leakage of plasma proteins caused by sexual stages damaging 
the mucosa (Williams 2005). On the other hand, the mucin adherent layer in the oregano treated group was of similar thickness to that in controls on dpi 3. The thickness of the mucin adherent layer is the result of the balance between the rate of mucin secretion and the rate of mucin layer degradation (Smirnov et al. 2004). Similarity of the mucin layer thickness in the jejunum between the oregano treated groups and the diet with anticoccidial drug despite the differences in the number of meronts could indicate the beneficial effect of oregano on the mucin quantity during the period of high multiplication of meronts in the jejunum. Excessive mucin secretion only in the coccidia infected group on dpi 10 of the experiment can result in the increase in endogenous nutrient losses and impairment of the nutrient absorption found during intestinal inflammatory processes (Koutsos and Arias 2006). On the other hand, due to the reduction of the mucin layer, nutrient retention by animals in both groups, i.e. treated with oregano and with anticoccidial drug should be increased. It is also noteworthy that the quantity of mucin in the intestine in the coccidia infected animals fed the diet supplemented with oregano is consistent with the increased quantity of IgM+ cells and the functional activity of phagocytic cells. It is supposed that T-cell mediated inflammatory response enhances mucogenesis (Smirnov et al. 2004; Collier et al. 2007). Our current experiment showed that the highest density of the mucin adherent layer was consistent with severe infiltration of studied $\mathrm{T}$ cell subpopulations as it can be seen only in the coccidia infected group. The influence of oregano on mucin production and its degradation is not clear. Oregano could possibly influence the mucin adherent layer thickness by initiating a higher rate of mucin production and jejunal mucosal turnover resulting in the increased mucin layer thickness, which may have a protective effect against the coccidia. A decreased biodegradation of mucin by suppressing of the bacteria having this activity could also play an important role. Previous studies showed that both mucin biosynthesis and secretion may be changed by the presence of bacteria, bacterial lipolysaccharide, and products of bacterial fermentation (Mack et al. 2003; Smirnov et al. 2005). Finally, oregano demonstrated antibacterial activity in vitro and in vivo against a number of bacteria (Burt 2004; Burt et al. 2005). The present data are the first to be in a relationship with the role of oregano to coccidia induced enteritidis and thickness of the mucin layer.

In conclusion, results of this study show that supplementation of oregano to the diet of chickens infected with $E$. acervulina has a modulating effect on some peripheral blood cell indicators and functional aspects of phagocytic cells. The positive effect of oregano components was also revealed on the mucin quantity and its turnover in the jejunum. The data indicate that the decrease in the number of meronts in the jejunum could be partly an immunological phenomenon induced by supplementation of oregano to the feed. A relationship of mucogenesis in the chicken intestine with the inflammatory process influenced by etheric oil requires further investigation.

\section{Dynamika črevného mucínu a odpoved' leukocytov u kurčiat infikovaných Eimeria acervulina a kŕmených diétou obohatenou oreganom}

Študovali sme účinok oreganom obohatenej diéty na dynamiku hlienu v tenkom čreve, leukocyty periférnej krvi a imunokompetentné bunky jejuna, u brojlerových kurčiat ROSS 308 infikovaných kuracími oocystami Eimeria acervulina (E. acervulina). Kurčatá 1. a 2. skupiny boli od vyliahnutia kŕmené komerčnou diétou bez antikokcidík, diéta kurčiat 3 .

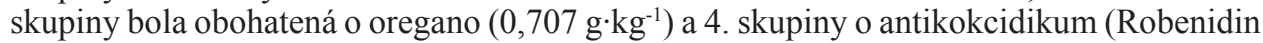
hydrochlorid - $\left.33 \mathrm{mg} \cdot \mathrm{kg}^{-1}\right)$. Na 12 . deň kurčatá 2., 3. a 4. skupiny boli inokulované oocystami E. acervulina $\left(25.10^{3}\right)$. Vzorky boli odoberané na 3., 10. a 17. deň po infekcii (dpi). V krvi bol na 3. dpi zistený signifikantne zvýšený počet leukocytov v 3. skupine v porovnaní s 1. 2. a 4. skupinou, vyššia hustota IgM+ buniek v skupine 3 oproti skupine 2, a na 10. 
dpi fagocytárna aktivita v skupine 3 bola vyššia ako v skupine 1 . Na 10. dpi sa počet jejunálnych CD4+ a CD8+ buniek v 3 skupine, napriek vyššej hustote merontov E. acervulina, zhodoval s hodnotami 4. skupiny. Množstvo adherentného mucínu v jejune kurčiat 3. skupiny bolo podobné ako vo 4. skupine. Počty oocýst vo féces boli nižšie v skupine 3 oproti skupine 2 . Z výsledkov vyplýva, že suplementácia oregana v diéte kurčiat infikovaných E. acervulina mala modulačný účinok na niektoré krvné parametre a funkciu fagocytov. Priaznivý účinok zložiek oregana sa tiež prejavil na množstve mucínu a jeho obnovení v jejune, čo sú prvé údaje v súvislosti s oreganom a kokcídiami.

\section{Acknowledgement}

This work was supported by the Grant Agency for Science of the Slovak Republic VEGA -1/0609/09, 1/0144/10, APVV-20-041605 and project INFEKTZOON - Centrum of excellence for infections of animals and zoonoses, on the basis of support by the operational Research and Development Programme financed by the European Regional Development Fund.

\section{References}

Botsoglou NA, Christaki E, Fletouris DJ, Florou-Paneri P, Spais AB 2002: The effect of dietary oregano essential oil on lipid oxidation in raw cooked chicken during refrigerated storage. Meat Sci 62: 259-265

Burt SA 2004: Essential oils: their antibacterial properties and potential applications in foods-a review. Int J Food Microbiol 94: 223-253

Burt SA, Vlielander R, Haagsman HP, Veldhuizen JA 2005: Increased activity of essential oil components carvacrol and thymol against Escherichia coli O157: H7 by addition of food stabilizers. J Food Prot 68: 919-926

Carrington C, du Plessis A, Naidoo V 2007: Index of Veterinary Specialities. Johncom publishers, Johannesburg, $38-40 \mathrm{pp}$

Chapman HD 1998: Evaluation of the efficacy of anticoccidial drugs against Eimeria species in the fowl. Int J Parasitol 28: 1141-1144

Christaki E, Florou-Paneri P, Giannenas I, Papazahariadou M, Botsoglou NA, Spais AB, 2004: Effect of a mixture of herbal extracts on broiler chickens infected with Eimeria tenella. Anim Res 53: 137-144

Collier CT, Hofacre CL, Pavne AM, Anderson DB, Kaiser P, Mackie RI, Gaskins HR 2007: Coccidiainduced mucogenesis promotes the onset of necrotic enteritis by supporting Clostridium perfringens growth. Vet Immun Immunopathol 122: 104-115

Garcia V, Catalá-Gregori P, Hernández F, Megías MD, Madrid J 2007: Effect of formic acid and plant extracts on growth, nutrient digestibility, intestine mucosa morphology, and meat yield of broilers. J Appl Poult Res 16: 555-562

Giannenas I, Florou-Paneri P, Papazahariadou M, Christaki E, Botsoglou NA, Spais B 2003: Effect of dietary supplementation with oregano essential oil on performance of broilers after experimental infection with Eimeria tenella. Arch Anim Nutr 57: 99-106

Harper CG, Makatouni A 2002: Consumer perception of organic food production and farm animal welfare. Br Food J 104: 287-299

Juhás Š, Bujňáková D, Rehák P, Čikoš Š, Czikková S, Veselá J, Il'ková G, Koppel J 2008: Anti-inflammatory effects of thyme essential oil in mice. Acta Vet Brno 77: 327-334

Koutsos EA, Arias VJ 2006: Intestinal ecology: Interactions among the gastrointestinal tract, nutrition, and the microflora. J Apll Poult Res 15: 161-173

Lillehoj HS, Bacon LD 1991: Increase of intestinal intraepithelial lymphocytes expressing CD8 antigen following challenge with Eimeria acervulina. Avian Dis 35: 294-301

Mack DR, Ahrne S, Hyde L, Wie S, Hollingsworth MA 2003: Extracellular MUC3 mucin secretion follows adherence of Lactobacillus strains to intestinal epithelial cells in vitro. Gut 52: 827-833

Manual of Veterinary Parasitological Laboratory Techniques. Ministry of Agriculture, Fisheries and Food. Reference book 418, Her Majesty's Stationery Office, London, 1989, 7-17

Mareček D, Procházková J 1986: Selected diagnostic methods of medical immunology. Avicenum Prague, 219 p. (In Czech)

Naidoo V, MvGaw LJ, Bisschop SPR, Duncan N, Eloff JN 2008: The value of plant extracts with antioxidant activity in attenuating coccidiosis in broiler chickens. Vet Parasitol 153: 214-219

Pavlišinová A, Danielovič I 2007: The content of essential oil and major effective components of essential oil monitored in sage (Salvia officinalis L.). Proc. Slovak Centre of Agricultural Research - Institute of Agroecology 23: 205-212

Peek HW, van der Klis JD, Vermeulen B, Landman WJM 2009: Dietary protease can alleviate negative effects of a coccidiosis infection on production performance in broiler chickens. Anim Feed Sci Technol 150: $151-159$ 
Revajova V, Pistl J, Levkut M, Marcin A, Levkutova M 2010: Influence of oregano and salvia extracts on lymphocyte subpopulation and functional activity of blood phagocytes and lymphocytes in chickens. Food Agricult Immunol 21: 307-316

Smirnov A, Sklan D, Uni Z 2004: Mucin dynamics in the chick small intestine are altered by starvation. J Nutr 134: 736-742

Smirnov A, Perez R, Sklan ARD, Uni Z 2005: Mucin dynamics and microbial populations in chicken small intestine are changed by dietary probiotics and antibiotic growth promoter supplementation. J Nutr $\mathbf{1 3 5}$ : $187-192$

Taylor DJ 2001: Effects of antimicrobials and their alternatives. Br Poult Sci 42 (Suppl.): 67-68

Thompson KL, Applegate TJ 2006: Food withdrawal alters small-intestinal morphology and mucus of broilers. Poult Sci 85: $1535-1540$

Tsutsumi Y 1972: Eimeria tsunodai sp. n. (Protozoa: Eimeriidae) a caecal coccidium of Japaneses quails (Coturmix coturmix japonica). Jap J Vet Sci 34: 1-9

Vekiari SA, Oreopoulou V, Tzia C, Thomopoulos CD 1993: Oregano flavonoids as lipid antioxidants. J Am Oil Chem Soc 70: 483-487

Větvička V, Fornusek L, Kopeček J, Kaminkova J, Kasparek L, Vranova M 1982: Phagocytosis of human leukocytes: A single micromethod. Immun Lett 5: 97-100

Whitt DD, Savage DC 1988: Influence of indigenous microbiota on activities of alkaline phosphatase, phosphodiesterase I, and thymidine kinase in mouse enterocytes. Appl Environ Microbiol 54: 2405-2410

Williams RB 2005: Intercurrent coccidiosis and necrotic enteritis of chickens: rational, integrated disease management by maintenance of gut integrity. Avian Pathol 34: 159-180 